\title{
TALENT DEVELOPMENT IN THE WORLD OF CLASSICAL MUSIC AND VISUAL ARTS
}

\author{
Linda Jarvin \\ Paris College of Art \\ 15 rue Fenelon, Paris, France, 75010
}

\begin{abstract}
In this article, we propose to explore the developmental trajectories of children displaying gifts and abilities in the domains of (classical) music and in visual arts. A developmental model for talent development that was developed in the domain of classical music will be briefly presented and its applicability in the field of visual arts will be discussed.
\end{abstract}

Key words: giftedness and talent. developmental models, classical music. visual arts, contemporary art

\section{Introduction}

You're 13 years old, and you've been practicing for several hours every day for at least a decade. Today is your chance to prove your promise to the admissions committee at a highly competitive American conservatory. You have 10 minutes. 10 minutes to prove to the school that you should be the chosen one among hundreds of applicants. Fewer than $10 \%$ of the hopefuls who have prepared for this day as arduously as you have will benefit from the teaching and mentoring of this conservatory's internationally acclaimed faculty. This is the 10-minute audition, and it's the standard in many performing arts fields.

What can a jury discern during the 10-minute audition? What manifest and latent talent and abilities are reviewed? What implicit or explicit model of talent development is in play, and to what extent is this model of talent development applicable in the nonperforming arts, and specifically in the visual arts?

In the first part of this article we will review and discuss our conceptions and definitions of talent. We will then review an empirically grounded model of talent development in the performing arts (classical music) and discuss its applicability to the field of visual arts.

We will conclude with some thoughts on the societal implications of our conceptions of giftedness for identification and intervention of talented youth.

\section{Definitions of talent}

The field of gifted and talented research and special programming is well established in the United States (Jolly \& Robins, 2016), and has been federally funded for close to 30 years. The Jacob K. Javits Gifted and Talented Students Education Act of $1988^{1}$ is the

${ }^{1}$ http://congressionalresearch.com/98-909/document.php?study=The+Javits + Gifted + and + Ta lented+Students+Education+Program+Background+and+Funding accessed on November 13, 2016. 
federal education act for gifted and talented education. The Javits Act defines talented and gifted students as those who give evidence of high performance capability in areas such as intellectual, creative, artistic, or leadership capacity or in specific academic fields. There is not as much consensus in many European countries, such as France, where there is still a debate about whether or not students with abilities beyond those of the majority should receive special attention and programing. For many in the French debate, treating students equally means providing them with the same educational opportunities, and to provide different opportunities for different groups of students would be unfair and contrary to the ideal of égalité.

On both continents the definitions of talent, high ability or giftedness are numerous and sometimes contradictory, yet the definition is the key to deciding on how talent can be identified, nurtured and assessed in the short and long term.

There is currently a dearth of research on long-term assessment of talent outside the areas of sports psychology and corporate talent management, with little research on other forms of talent development.

We therefor start by stating our theoretical framework and the premises we set for the rest of this article: talent is domain-specific, developmental, and incremental, and depends on the interaction between personal (e.g., general intelligence, deliberate practice to push your limits and recover after failure) and environmental factors (e.g., supportive environment and social appreciation of the skills, educational environmental interventions).

\section{Theoretical framework and premises}

Traditionally, abilities, competencies, and expertise have been viewed as separate and largely distinct constructs and research areas within the broader field of psychology. In this view, abilities are regarded as largely innate capabilities; competencies are acquired basic skills; and expertise reflects high-level mastery of skills (Sternberg, 1998; Sternberg, 2000). We believe that the three constructs are inextricably linked, and that abilities are to be measured as developing competencies, which in turn can be transformed into various forms of developing expertise, and at the final stage, into scholarly productivity or artistry (SP/A). Abilities, then, are nascent forms of developing expertise. As a result, abilities, as well as the competencies and expertise that develop from them, are flexible and modifiable in nature. We argue that, in the domain of musical talent, giftedness, in its early manifestation, is defined by the efficient yet comprehensive development of ability into competence in a domain. During the middle stage, competence is transformed by the gifted individual with the help of his or her teachers into precocious achievement of expertise in creative problem finding and solving. Finally, we view giftedness in adulthood as SP/A, taking the form of unique contributions to a field or to a domain.

Our model is based on empirical work, and also draws upon other developmental models of high abilities (for an exhaustive overview of different models, see Shavinina, 2009), specifically those of Bloom (1985), Tannenbaum (1983), and Gagné (2003), as described in more detail in previous publications (see for example: Jarvin \& Subotnik, 2014 or Sternberg, Jarvin \& Grigorenko, 2011).

The empirical research was conducted with highly gifted and successful classical musicians, music students and "gatekeepers" of the music world (Subotnik, Jarvin, Moga, 
\& Sternberg, 2003; Subotnik, \& Jarvin, 2005; Subotnik, Jarvin, Thomas \& Lee, 2016). The model defines giftedness as a transitional process in which different characteristics contribute to the transformation of abilities into competencies and expertise, and in exceptional cases, into scholarly productivity or artistry. This transformation is made possible through the interaction of innate abilities and context, as specified at each stage. The model is described in some detail in the next section.

\section{Talent development in the domain of classical music}

Subotnik, Jarvin and colleagues (Jarvin \& Subotnik, 2006, Subotnik \& Jarvin, 2005, Subotnik, Jarvin, Moga \& Sternberg, 2003) conducted a series of interviews with students and faculty at three highly selective classical music conservatories on the East Coast of the United States, and also interviewed "gatekeepers" for professional classical musicians, such as major newspaper music critics, or artistic directors of major opera houses. Based on the responses from these interviews, they developed a model of talent development and high abilities specifically in the domain of (classical) music. The model was further refined with additional interviews with very young students and their faculty (Subotnik, Jarvin, Thomas \& Lee, 2016). The study included three groups of performers: brass, string and vocal performers. This limits the generalizability of the results and impacts the biological age at which a transition from one stage to the next is to be expected, since string performers typically start serious training at a much younger age than singers.

We present here the main results in the order that the factors appear in our model (see table), i.e. we will first discuss the factors perceived as being of the greatest importance in the early stages of a musician's development (analytical abilities, technical proficiency, parental support, teachability, teacher-student relationship, external rewards, persistence, intrinsic motivation), then move to those perceived as gaining importance in the middle stages (knowing one's strengths and weaknesses, self promotion, playing the game, social skills, and self-confidence), and finally review those that matter most in later stages and those that are viewed as innate (risk taking, musicality, and charisma).

\section{Learn Quickly and Analyze Patterns and Structures}

As did gatekeepers, faculty pointed out the importance for beginning musicians to practice in order to (a) challenge the teacher, and (b) refine their understanding of the patterns and structures so that when they enter a professional career, they have mastered the ability to learn quickly.

\section{Technical Proficiency}

All teachers agreed that technical proficiency is important, and that it is essential to acquire it early. It should be noted here that the age that constitutes "early" depends on the domain, i.e. a string player will often start when he or she is a child, while a voice student can start practicing in late adolescence without being at disadvantage.

Gatekeepers, witnessing a much more limited range of technical proficiency, considered the possibility that a technical flaw can be interesting, and that passion can sometimes make up for lack of technical proficiency. According to one gatekeeper, "somewhat flawed" is better than "push the play button". 
$\stackrel{\frac{\pi}{2}}{\frac{\pi}{\digamma}}$

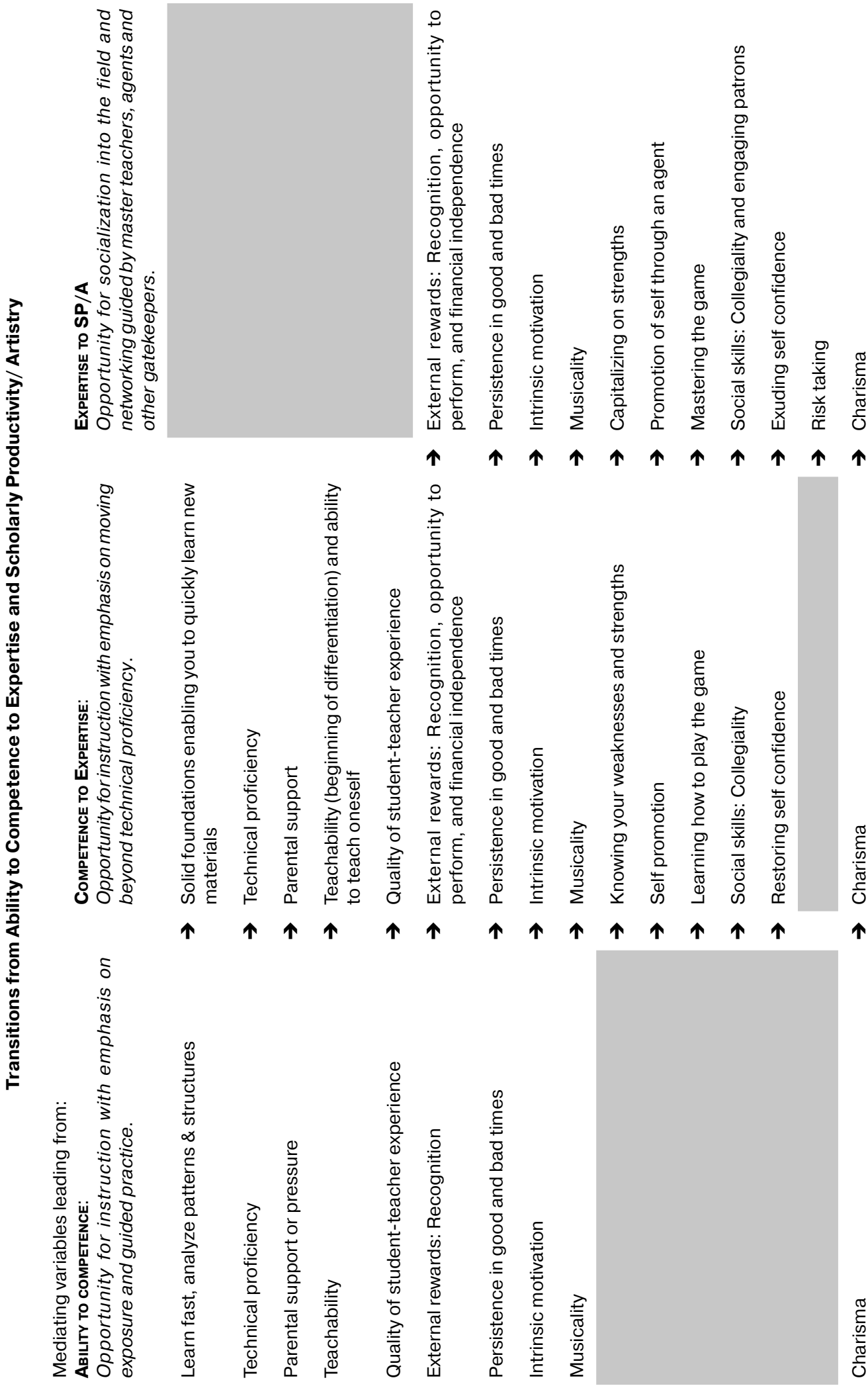




\section{Parental Support or Pressure}

Faculty noted the importance of a combination of parental support and pressure in the early stages, developing into a need for support as students grow older, and becoming less relevant as they enter a professional career. This mirrors the gatekeepers' perception, since by the time they interact with an artist, the artist is typically old enough to have gained some independence. This is also congruent with results reported by Davidson, Sloboda, and Howe (1995/96), showing that the children they interviewed with higher musical achievement were initially strongly supported by their parents, but this parental support diminished around age 11 and was replaced with strong intrinsic motivation. Again, it is important to note how the musical instrument (string, brass, voice) impacts the importance of this factor, with students of string instruments starting at a much younger age, and thus relying more on their parents' pressure (to practice, to go to class, etc.).

\section{Teachability}

Gatekeepers and teachers alike pointed out its shifting role of over time: It is perceived as an essential quality in young students, and often determines whether or not a conservatory faculty will accept to take on a student. As students grow older however, and as they enter professional careers, it becomes more important that they become able to teach themselves and learn to "bite back", arguing for and defending their choices to their teachers.

\section{Quality of the Student-Teacher Experience}

Teachers are the center of young musicians' lives for many years, and, not surprisingly, the faculty we interviewed insisted that a positive teacher - student relationship in the early years is "incredibly important, maybe the most important thing". Several interviewees talked about the legendary teachers they themselves had been apprenticed with, while recognizing (thus agreeing with gatekeepers), that the teacher's role diminishes over time.

\section{External Rewards}

Teachers insist on the importance of having opportunities to perform and the availability of rewards and other forms of recognition. Differences also exist between solo players and orchestra members.

The importance of public recognition is also acknowledged by gatekeepers, who, because of the high-level performers they interact with, point out the difference between seeking recognition (which they perceive as valuable and laudable) and seeking fame, which they perceive as the detrimental moment when being a star becomes more important than being an artist.

Though faculty agree with gatekeepers that "recognition is much more important than money", when probed, they describe the increasing importance and value of financial rewards as a musician develops - not for the money per se, but for the independence to fully concentrate on music that it affords.

\section{Persistence through good and bad times}

Gatekeepers and faculty agree both on the importance of persistence, and share examples of how even very well-known artists experience good and bad times throughout 
their careers. This is related to the combination of perseverance and passion defined as grit (Duckworth, Peterson, Matthews, \& Kelly, 2007).

\section{Intrinsic Motivation}

When gatekeepers reviewed the list of variables in our interview schedule, they clumped together intrinsic motivation, persistence, and self-confidence as qualities possessed by artists who come to their attention. Teachers, on the other hand, focused more on the importance of the perceived intrinsic motivation in their students when making admissions decisions to pre-college and college conservatory programs, as well as the ways in which a teacher can enhance motivation by providing students with opportunities to be creative and to perform (even to other students). Several anecdotes showing how even very accomplished performers continue to doubt themselves and actively work on their selfconfidence seem to indicate that the intrinsic motivation of performers is not so much linked to self efficacy as it is to the 'need' to pursue one's art (see O'Neill \& McPherson, 2002, for a discussion).

\section{Knowing one's own strengths and weaknesses}

Teachers agree that at the early stages it is not important for students themselves to know their strengths and weaknesses. As one string faculty pointed out, it is not constructive to talk to students about their weaknesses, but that it is important to point out to students what they do well and what they can improve. Many teachers view it as their role to point out to students what their areas of relative weakness are and to focus specifically on those.

As students grow older though, it is important for them to develop this self-knowledge, so that they can make the right choices for the future.

Teachers can help their students become more aware of their strengths as they develop, but not all students are willing to listen to that advice.

Once a musician reaches the later stages and becomes professional, it is clearly important to know strengths and weaknesses in order to be able to capitalize on strengths. The gatekeepers we interviewed perceived the question of knowing one's own strengths and weaknesses slightly differently, with it not mattering so much that the artist had this self-knowledge, as long as they are willing to accept the gatekeepers' judgment of strength. This can be explained by the role gatekeepers play: whereas teachers are trying to provide their students with information that the students can use in continuing their own development, gatekeepers are primarily looking to fill a needed slot in a program.

\section{Self-promotion and Knowing How to Play the Game}

Self promotion and "knowing how to play the game" were grouped together by most of our participants, and recognized as important for the middle and later stages in a musician's career, but not at an early age.

Teachers and gatekeepers agreed that self-promotion is necessary for success as a performer ("I think a musician is entitled to do everything that they can do to promote themselves"), and knowing when and how to promote oneself is part of being effective at securing jobs.

Most teachers believe that they need to prepare their older students somewhat to "playing the game" in the form of being graceful in success and failure, and engendering 
a reputation as a professional. They also discuss the variable difference of "game playing" depending on the professional circumstances (freelance vs. orchestra for example).

\section{Social Skills}

According to our study subjects, social skills will not trump talent, but if two equally talented individuals are being considered, the one with good social skills will get the job or the kudos. Gatekeepers do not view social skills as merely etiquette or social graces, but rather as a form of professionalism. Being socially aware means being on time and prepared, returning phone calls, dressing appropriately. They contrasted professionalism with "knowing how to play the game", which they associated with self-promotion. From their perspective, when behavior too obviously reflects self-promotion, it can backfire. At the later stages, once one is a professional musician, the differences in employment status (tenured orchestra member vs. soloist or freelancer) make all the difference.

\section{Self-confidence}

Reflecting on their students' experiences in highly competitive conservatory programs, faculty members noted the importance of students' ability to restore their self-confidence after becoming a small fish in a big pond, an experience that most of them went through and will continue to go through. Haroutounian (2002) refers to this as the "midlife crisis" of prodigies. Faculty also acknowledged, as did the gatekeepers, the continued need for self-confidence for performing artists at later stages in their trajectories. Artists need (1) to believe they have something important and unique to say and (2) to mask deep-seated needs for reassurance.

\section{Risk Taking}

Teachers and gatekeepers agreed on the vital importance of risk-taking, which they see as the key to true artistry. Faculty talked about the benefit of prodding students to take risks while they are still in the relatively protected conservatory environment, so that they can go on to become risk-taking artists.

\section{Musicality}

Faculty responses to the question of musicality varied depending on their field: for string and brass faculty, musicality is the ability to truly communicate through music, as opposed to the more physical dexterity. For voice faculty however, the instrument, which in this case is the voice, is more important than the musicality, in that teachers and coaches can much enhance the performance of someone who has a great instrument. The voice is the pre-requisite. On the topic of musicality faculty responses thus differed from those of gatekeepers, who tended to view musicality as something innate. This difference of perception can be due to the fact that gatekeepers encounter a much more narrow range of performers than do faculty.

\section{Charisma}

According to our participating gatekeepers, there are two kinds of charisma: one centered on the artist and one centered on the music. Artists of the first kind draw people 
to them because their presence is larger than life ("Look at me!"). Another kind arises from their performance. This kind of charisma evokes, "Listen to this!" instead of "Look at me". The gatekeepers valued both types of charisma, but recognized the power of the first type to draw audiences and attention. Teachers overall agree with this statement, and one of them described it as increasingly important on today's scene.

\section{Summary and Implications}

To summarize, the development of abilities into competencies relies on interactive genetic and environmental components, including intrinsic motivation and acuity in language, mathematics, or spatial reasoning. With high-quality instruction, a child can develop these abilities into competencies. The instruction should emphasize exposure to and guided practice in the skills and knowledge of the domain. The effectiveness of this instruction is mediated by a number of factors, including how fast the student can learn, the proficiency the student can attain in the application of skills and knowledge, parental support or pressure, the student's teachability (i.e., willingness and openness to being taught), the quality of the student's experience in school, the match between the student's and school's expectations, the teacher's ability to identify strengths and weaknesses and provide students with appropriately challenging classes, the availability of external rewards such as praise and recognition, and the student's persistence through good and bad times.

At the second stage, typically experienced during adolescence or early adulthood, competency develops into expertise through continued opportunity for instruction, with an emphasis on moving beyond mastery of skills and knowledge to exercising creative problem finding and solving. New mediating variables at this stage are responsibility for managing one's strengths and weaknesses, self-promotion, learning how to play the game, social skills, and restoring self-confidence.

The last transition in our model is from expertise to scholarly productivity or artistry (SP/A), which is facilitated in the academic world by the opportunity for socialization into the field and networking guided by mentors and other gatekeepers. New mediating variables at this stage are a willingness to take risks and charisma.

\section{Talent development in the domain of visual arts}

The model of talent development in classical music described above has been expanded to other domains, including academics (Jarvin \& Subotnik, 2014; Jarvin \& Subotnik 2015) and mathematics (Subotnik, Pillmeier, \& Jarvin, 2009). We are now collecting data to adapt it to the domain of visual arts, and make the following hypotheses of what the model will look like.

The factors that we hypothesize not to have the same importance in the visual arts as they do in classical music are charisma, technical proficiency, and teachability, while we think that the availability of external rewards is more important in the visual arts than in music. The ability to learn quickly and musicality are also different in a model for the visual arts. The factors and their importance across developmental stages, and how they differ in the two models is discussed below.

Persistence through good and bad times is critically important in the visual arts and increasingly so as one's career develops. The trends in contemporary art are continuously evolving, and an artist who is "hot" at an art fair one year may no longer be so at the 
following year's edition. In addition, there are no stable employment opportunities in the visual arts equivalent to an orchestra position in the domain of classical music, so artists need to continuously seek residency opportunities, gallery representation, etc.

Self confidence is important in the visual arts just like it is in the performing arts. Artists exhibit their work publicly, and, starting during their schooling, they are exposed to group critiques where their ideas and the realization of those ideas are discussed. Contrary to a musician who often interprets someone else's composition, artists exhibit their own creations, which are often very personal.

Knowing your strengths and weaknesses and accurate self judgment has been shown to be important in the domain of music (Kozbelt, 2007), and it is in the visual arts as well, but the importance is tempered by the fluctuations in the contemporary art market, where trends and pricing can be more influenced by "being the right person at the right time" (Thompson, 2008; Thornton, 2009).

Social skills are increasingly important over the development of a career, as they will help with securing artist residencies, gallery representation, invitations to art fairs, etc.

The Ability to learn quickly and to analyze structures and patterns is slightly different in the visual arts. Contemporary art is increasingly conceptual, and the ideas count as much as their physical expression, so the factor could be relabeled conceptual thinking. Because of the importance of ideas, we also propose to add an additional factor:

Oral and written communication skills, which are essential to communicate your concepts through artist's statements, gallery talks, interviews, critiques and other presentations of their art that contemporary artists engage in.

The increased focus on concepts and ideas has also changed the role of Technical proficiency in contemporary art in two aspects. First, an artist can be recognized for his or her work even if it is technically produced by someone else. Many contemporary artists (e.g., Jeff Koons) have studios with employees who translate their ideas into physical manifestations (Thompson, 2008). Secondly, ideas can be expressed very simply, without relying on traditional techniques of painting, drawing or sculpture. Duchamp's Fountain (a mass-manufactured urinal signed by the artist with a pseudonym) is one early example, and Marina Abramovi sitting in a chair and letting museum goers sit across from her a more recent one (Artforum, 2010). This change is reflected in art education, where the distinction between art and craft (Davis, 2016) has lead some institutions of higher education in the arts minimize the teaching of technique and skills in favor of conceptual thinking and critical theory.

It also influences teachability, for if there are no skills or techniques to be taught the role of the master teacher changes.

Intellectual Risk taking (i.e. expression of novel and unexpected ideas and concepts) remains important in the visual arts, and studies have shown a positive correlation between intellectual risk-taking and creative self-efficacy (Beghetto, 2006).

In the domain of contemporary visual arts, it is important to Know how to play the game, but this can be done by the artists herself or her gallerist or agent. If the artist is not required to perform in front of a live audience, a well-chosen representative can play that part, and some gallerists are as well-known as the artists they represent (e.g., Larry Gagosian and Marian Goodman).

Intrinsic motivation, Self-promotion (or the securing of someone to promote you), and the Availability of external rewards are as important in the visual arts as they are in classical 
music, the latter of the three maybe even more important because of the volatility of the contemporary art market and the possibility of significant earnings.

Because careers in the visual arts typically start in young adulthood rather than in adolescence, Parental support and / or pressure is less of a factor, as is Charisma, because there is no performance and you can display great conceptual thinking without personal charisma.

In the model, Musicality is replaced by a factor that could be labeled visual cast of mind or visual acuity, which has been empirically shown to advantage artists over nonartists in drawing and visual analysis (Kozbelt, A. \& Seeley, 2007).

\section{Conclusion}

Given this proposed model, what would be a suitable equivalent of the 10-minute audition in the field of visual arts? Because of the growing importance in contemporary art of conceptual thinking, a speculative market, and the importance of "being the right person in the right place at the right time" it is much harder to imagine one equivalent of the 10-minute audition. For art college admissions and gallerists, the portfolio review remains the process of choice, coupled today with a review of the artists' (social) media presence. There is no equivalent of the 10-minute audition, and a creative person's output over a longer range of time is, and should be, considered.

For educators, the model of talent development discussed here has clear implications: If a wide spectrum of cognitive and non-cognitive factors contributes to success in classical music and in the visual arts, then we should explicitly take those factors into account when developing and reviewing curricula in order to give all students a chance to succeed. As educators, we can help make tacit knowledge explicit, so that all students have a similar understanding of the importance of social skills, regardless of their family background.

\section{Acknowledgements}

The ideas expressed in this manuscript were first presented at the Inaugural Invited EuropeanAmerican Summit on Talent Development organized by the American Psychological Association, and the authors wish to thank the conference organizers for the opportunity to participate.

\section{REFERENCES}

Artforum on-line, June 6, 2010, https://www.artforum.com/diary/id=25782 accessed January 18, 2017.

Beghetto, R.A. (2006). Creative self-efficacy: Correlates in middle and secondary students. Creativity Research Journal, 18(4), 447-457. doi: 10.1207/s15326934crj1804_4

Bloom, B. (1985). Developing talent in young people. New York: Ballantine.

Davidson, J.W., Sloboda, J.A., \& Howe, M.J.A. (1995/96). The role of parents and teachers in the success and failure of instrumental learners. Bulletin of the Councilfor Research in Music Education, (127), 40-44.

Davis, B. (2016, April). Connoisseurship and critique. e-flux journal \#72: http://www.e-flux.com/ journal/72/60496/connoisseurship-and-critique/ (accessed January 18, 2017).

Duckworth, A.L., Peterson, C., Matthews, M.D., \& Kelly, D.R. (2007). Grit: Perseverance and passion for long-term goals. Journal of Personality and Social Psychology, 92(6), 1087-1101. doi: 10.1037/0022-3514.92.6.1087.

Gagn , F. (2003). Transforming gifts into talents: The DMGT as a developmental theory. In N. Colangelo \& G.A. Davis (Eds.). Handbook of gifted education ( $3^{\text {rd }}$ ed., pp. 60-74). Boston: Allyn and Bacon. 
Haroutounian, J. (2002). Kindling the spark: Recognizing and developing musical talent. Oxford, UK: Oxford University Press. doi: 10.2307/3399863.

Jarvin, L., \& Subotnik, R. (2006). Understanding Elite Talent in Academic Domains : A Developmental Trajectory from Basic Abilities to Scholarly Productivity/Artistry. In F.A. Dixon, \& S.M. Moon (Eds.). The Handbook of Secondary Gifted Education. (pp. 203-220). Waco, TX: Prufrock Press.

Jarvin, L. \& Subotnik, R. (2014). Understanding elite talent in academic domains: a developmental trajectory from basic abilities to scholarly productivity / artistry. In S. Moon \& F. Dixon (Eds.). The Handbook of Secondary Gifted Education (2 ${ }^{\text {rd }}$ ed., pp. 217-235). Waco, TX: Prufrock Press.

Jarvin, L. \& Subotnik, R.F (2015). Academic Talent Development in North America and Europe. Asia Pacific Education Review, 16 (2), 297-306. doi: 10.1007/s12564-015-9370-0.

Jolly, J.L. \& Robins, J.H. (2016). After the Marland Report: Four Decades of progress? Journal of Education of the Gifted, 39(2), 132-150. doi: 10.1177/0162353216640937.

Kozbelt, A. (2007). A quantitative analysis of Beethoven as self-critic: implications for psychological theories of musical creativity. Psychology of Music, 35(1), 144-168. doi: 10.1177/0305735607068892.

Kozbelt, A. \& Seeley, W.P. (2007). Integrating art historical, psychological, and neuroscientific explanations of artists' advantages in drawing and perception. Psychology of Aesthetics, Creativity, and the Arts, 1(2), 80-90. doi: 10.1037/1931-3896.1.2.80.

O’Neill, S.A. \& McPherson, G.E. (2002). Motivation. In R. Parncutt \& G.E. McPherson (Eds.). The science and psychology of music performance (pp. 31-46). New York: Oxford University Press.

Shavinina, L.V. (Ed.) (2009). International Handbook on Giftedness. New York, NY: Springer. doi: 10.1007/978-1-4020-6162-2.

Sternberg, R.J. (1998). Abilities are forms of developing expertise. Educational Researcher, 27, 11-20. doi: 10.3102/0013189X027003011.

Sternberg, R.J. (2000). Giftedness as Developing Expertise. In K.A. Heller \& F.J. Mönks (Eds.), International handbook of giftedness and talent (2nd ed., pp. 3-137). New York: Elsevier. doi: 10.1016/B978-008043796-5/50004-8.

Sternberg, R.J., Jarvin, L. \&. Grigorenko, E.L. (2011). Explorations in Giftedness. New York: Cambridge University Press. doi: 10.1017/CBO9780511778049.

Subotnik, R.F. \& Jarvin, L. (2005). Beyond expertise: Conceptions of giftedness as great performance (pp. 343-357). In R.J. Sternberg and J.E. Davidson, (Eds.). Conceptions of Giftedness ( $2^{\text {nd }}$ ed., 343-357). New York: Cambridge University Press. doi: 10.1017/cbo9780511610455.020.

Subotnik, R.F., Jarvin, L., Moga, E., Sternberg, R.J. (2003). Wisdom from gatekeepers: Secrets of success in music performance. Bulletin of Psychology and the Arts, 4(1), 5-9.

Subotnik, R.F., Jarvin, L., Thomas, A., \& Lee, G.M. (2016). Transitioning musical abilities into expertise and beyond: The role of psychosocial skills in developing prodigious talent. In G. McPherson (Ed.) Child Prodigies in Music (pp. 279-293). Oxford, UK: Oxford University Press. doi: 10.1093/ac prof:oso/9780199685851.003.0011.

Subotnik, R.F., Pillmeier, E., and Jarvin, L. (2009). The Psychosocial Dimensions of Creativity in Mathematics: Implications for Gifted Education Policy. In R. Leikin, A. Berman, \& B. Koichu. Creativity in Mathematics and the Education of Gifted Students (pp. 165-180). Rotterdam, Netherlands : Sense Publishers.

Tannenbaum, A.J. (1983). Gifted children: Psychological and educational perspectives. New York: McMillan.

Thompson, D. (2008). The \$12 million stuffed shark: The curious economics of contemporary art. New York, NY: Palgrave Macmillan.

Thornton, S. (2009). Seven days in the art world. New York, NY: W.W. Norton \& Company.

(C) Jarvin, L., 2017

\section{Article history:}

Received 9 February 2017

Revised 3 April 2017

Accepted 14 April 2017 
For citation:

Jarvin, L. (2017). Talent Development in the World of Classical Music and Visual Arts. RUDN Journal of Psychology and Pedagogics, 14 (2), 131-142.

Bio Note:

Linda Jarvin - Ph.D., Dean of the Paris College of Art (Paris, France). E-mail: linda.jarvin@ paris.edu

\title{
РАЗВИТИЕ ТАЛАНТА В ОБЛАСТИ КЛАССИЧЕСКОЙ МУЗЫКИ И ИЗОБРАЗИТЕЛЬНОГО ИСКУССТВА
}

\author{
Линда Джарвин \\ Парижский колледж искусств \\ 15 rue Fenelon, Paris, France, 75010
}

В статье предлагается рассмотреть траектории развития детей, одаренных в музыкальной сфере (прежде всего, сфере классической музыки) и в области изобразительного искусства. Кратко представлена модель развития таланта, разработанная применительно к классической музыке, а также обсуждается возможность ее приложения в сфере изобразительного искусства.

Ключевые слова: одаренность, талант, модели развития, классическая музыка, изобразительное искусство, современное искусство

\section{История статьи:}

Поступила в редакцию: 9 февраля 2017 г.

Принята к печати: 14 апреля 2017 г.

\section{Для цитирования:}

Джарвин Л. Развитие таланта в области классической музыки и изобразительного искусства // Вестник Российского университета дружбы народов. Серия: Психология и педагогика. 2017. T. 14. № 2. C. 131-142.

Сведения об авторе:

Линда Джарвин - Ph.D., декан Парижского колледжа искусств (Париж, Франция). E-mail: linda.jarvin@paris.edu 